\title{
Nationality as an element of identity in musical interpretation. Case study: Romanian performers
}

\author{
CRISTINA-NICOLETA ȘOITU, Lecturer PhD \\ "Gheorghe Dima" National Academy of Music, Cluj-Napoca \\ ROMANIA*
}

\begin{abstract}
The $20^{\text {th }}$ century is the period of time when the specificities of Romanian culture were identified and theoretically defined by notable authors such as Lucian Blaga (philosopher and poet) or Carmen Petra-Basacopol (musicologist and composer). The concept of "spatial horizon" or "Mioritic space" presented by Blaga in his well-known work The Trilogy of Culture affirms characteristics of Romanian spirituality and culture polished over time, and an author such as Carmen PetraBasacopol shows us the manner in which these ethnic patterns are reflected in music. This research paper intends to establish to what extent the national ethos is present in the musician-performer's identity and which are the technical-expressive abilities that correspond to the elements defined by the above-mentioned authors. The investigation methods are based on the research of the musical chronicles, but also the comparative analysis of the recordings belonging to nationally and internationally recognized Romanian performers. The validation of these premises will start from the case of musicians such as George Enescu or Dinu Lipatti (composers and performers alike), but will also follow the qualities appreciated in contemporary artists; in the case of the latter I will try to find out how perceptible nationality is as an identity element to those who were born in Romania and are living here, those who were born in the country, but continued their activity abroad, as well as of those who were both born and are living outside Romania (coming from a family of Romanian descent). At the same time, the study will try to provide a perspective on the advantages and disadvantages ethnic background might have in composing the interpretative strategy and in the field of artistic recognition.
\end{abstract}

Keywords: identity, musical performance, nationality, George Enescu, Dinu Lipatti

\section{Introduction}

A perfomer's interest for what is happening in their musical environment, but also in the artistic-cultural sphere in general, is essential for his or her professional development and its harmonization with the dynamics of this environment. In addition to individual study and stage experience, the informative side involves listening to recordings, attending concerts and recitals, with varied repertoires performed by musicians of different

\footnotetext{
*cristina_soitu@yahoo.co.uk
} 
nationalities, and analysing books, music-themed articles, or even opinions expressed in articles. From this perspective, of the researcher-performer, the theme proposed for the present study was materialized, a theme that includes a series of questions regarding nationality as an integral part of identity: is this notion valid in musical interpretation? If so, what are the qualities that would define Romanian performers? Are these still accepted today, when we are witnessing an ever-increasing tendency to unify diversity? In addition, what are the advantages and disadvantages of displaying these qualities? Local literature deals with the Romanian ethos, the characteristics of Romanian music (folk and cultivated), but there is no continuity of these observations regarding their reflection in the process of interpretation. There are also references in concert reviews about performers' qualities and some testimonies attesting to the requirements of the Romanian school (on the vocational-musical side). But there are no studies to outline the profile of Romanian performers, to highlight the features that may attest their nationality as a constitutive part of their identity.

To answer these questions I started from the definition of identity and noticed that it implies belonging, namely "awareness of the feelings of belonging (belonging to a family, country, people, culture, ethnicity, ideology, professional group)" (Șchiopu, 1997, p. 348), but also uniqueness, being “an active, affective and cognitive process" that "results from a subject's own experience that he/she exists and to be recognized, in relation to another, both as a singular being, but also identical, in his physical, mental and social reality. Personal identity is a dynamic construction of the unity of self-awareness through intersubjective relationships, verbal communication and social experiences. [...] Identity satisfies the inter- and intrapersonal need for coherence, stability and synthesis, which ensures permanence in existence" (Doron \& Parot, 1999, p. 380). The validity of the valorization of ethnicity as a feature of identity is thus confirmed. A musicologist like Carmen PetraBasacopol (1979) notes that "the notion of mioritic space" coined by Lucian Blaga, "was adopted by Romanian philosophy as a symbol of the specificity of ethnic spirituality" and describes the specific features of Romanian music in the work in which she analyzes its originality. But can we talk about a transfer of these characteristics (detailed in the next section of this article) also in the field of musical performance? We tried to confirm this premise by taking a closer look at several generations of artists (Enescu and Lipatti, but some of the contemporary ones as well), by consulting the media materials - articles, interviews, but also testimonies of those who researched the artistic activity of Romanian musicians.

We believe that this methodology is adequate to prove that nationality has been an important element in forming and polishing or affirming an artistic 
personality, but at the same time we believe that it may provide an overview of the advantages and disadvantages that this fact implies.

The study features in this sense the support of the idea of awareness of the qualities transmitted culturally in each performer's interior-psychological plane, this being the basis for further research on the artistic-interpretative process.

\section{The Romanian ethos}

In the following I will try to outline the main features of the Romanian ethos perceived in the cultural phenomenon in general, but also in the sphere of music, with accents on the typical aspects noticed by Lucian Blaga or Carmen Petra-Basacopol in reference works of the art literature of the twentieth century ${ }^{1}$.

Lucian Blaga (2011) sketched the "stylistic unity" of Romanian culture by imagining a "spatial horizon of the unconscious" defined as "a psychospiritual reality broadly structured and relatively self-sufficient, [...] deeper and more effective than a simple feeling would ever be". "Decisive for the stylistic structure of a culture," also called the "matrix space" or "mioritic space", a name borrowed from the title of one of the most valuable folk lyrical creations (Miorița), it circumscribes an attitude of resignation to one's fate, a feature deeply imprinted in the "ancestral Romanian soul." This denotes a solemnity in the face of transcendence, "a majestic resignation in the face of death," and the poem's allegory, death as a wedding, underlines the positivism and inner calm in which "the invincible nostalgia of returning to the bosom of nature" occurs, therefore it is not about a "madness of nothingness" but a "primary gesture of defending life" (Petra-Basacopol, 1979, p. 21). The great Romanian philosopher considers that these trajectories are most eloquently expressed in folk songs, especially in the intonations of doinas and ballads, which through their melodic shape imprint the space an "undulating" aspect (the correspondent of hills and valleys), and through the atmosphere they express melancholy and a probe into the depths of the soul: "The solidarity of the Romanian soul with the mioritic space bears a kind of slow paced, unconscious feature of buried fire, not of sentimental effervescence" (Blaga, 2011, p. 166).

Another feature "specific to the Romanian soul, the one that defines it best" (Petra-Basacopol, 1979, p. 23) is the 'dor' (longing), an untranslatable notion, which most often implies the feeling of sadness, of nostalgia, the pain as "serene resignation, 'mioritic,' in the face of death", as described by Doru Popovici (Petra-Basacopol, 1979, p. 23) or as "an aspiration of the soul to

\footnotetext{
${ }^{1}$ Trilogia culturii (Blaga) and L'originalité de la musique roumaine à travers les oeuvres de chambre et de scène d Enesco, Jora et Constantinesco (Petra-Basacopol).

2 The assertions belong to Constantin Brăiloiu, in the analysis by Carmen Petra-Basacopol.
} 
something it does not possess" (Petra-Basacopol, 1979, p. 23); the dor is sung in a state of loneliness, for oneself and not for the one to whom it is addressed, "as a hypostasis," "as an alter ego" and it places the feeling "in that spirit of nuance and of discreet sobriety, proper to the creation of our people" (Blaga, 2011, pp. 279, 282). We used the expression "dor cântat" (sung longing) voluntarily, because this feeling is most often rendered through the song, as Enescu also points out: "Romanian peasants carry the music in themselves. [...] It lessens the dreads that assault them, helps them to materialize their longing, that inexpressible nostalgia which devours their soul. Inspired by the sufferings of the Romanian people harassed by invaders, their music is painful and noble, even in the sprightly rhythms of fast dances" (Petra-Basacopol, 1979, pp. 2425). This longing is present in almost all folk creations (the emblematic song, however, is the doina, a genre with vocal predominance, with a parlandorubato rhythm, featuring accents that render the state of the one who performs it), but it also emerges in cultivated art, from poetry and sculpture to painting and music.

Thus, Carmen Petra-Basacopol (1979) draws attention to vocality as one of the defining features of Romanian music (also mentioning the Romanian terminology in which "to sing" defines both vocal and instrumental music), as well as a certain distinction given by exploring sensibility to the extent of transcendence. Melody appears as a constant of the Romanian musical compositional view, as we can see in Enescu and other composers of the twentieth century, and it is also the source from which the process of heterophony stems (Sandu-Dediu, 2017, p. 92).

Regarding cultivated music, Carmen Petra-Basacopol (1979) notices the introspection and sobriety arising from the Byzantine influences on Romanian music, which took over melismatic singing and the modal specificity of both Byzantine religious music and the folk one.

\section{Correspondences - characteristics of national identity in interpretation}

To see if these Romanian characteristics are reflected in musical interpretation, we analyzed the art of twentieth century personalities such as George Enescu and Dinu Lipatti.

\subsection{The case of $20^{\text {th }}$ century performers - George Enescu, Dinu Lipatti}

Marsick appreciated in George Enescu, from an early age, the "depth of style" (Malcolm, 2011, p. 61), which was also noted in the years of maturity, in his recordings or in stage appearances. The precedence of the message over the instrumental technique was the motto that he respected and transmitted to his disciples: "technique can be summed up in one word: music" (Malcolm, 2011, p. 179). He often asked those with whom he worked to find their own technical solutions to render the composer's musical intention. Another feature of his 
interpretation is vocality, as evidenced by a review from 1928: "what emerges from the strings resembles so well a singing voice that it does not immediately catch your attention. There is nothing but the sound, the perfect movement of the bow eliminates the musician, the violinist, it eliminates the bow itself. There is nothing reminiscent of the connection between the bow and the strings" (Malcolm, 2011, p. 178). In performer Enescu's mindset, the expression implies clarity and sobriety, as Richard Aldrich, a critic from the New York Times, mentioned in 1923, referring to the way in which Enescu played Bach and Leclair: "He is a musician and an performer devoted only to the presentation of music and not to the display of his own technical qualities. [...] There is without doubt a certain austerity in Mr. Enescu's playing, he cares very little about lascivious pleasures or the obvious feelings. In all of these, however, there is a rich musical feeling, expressed with strength" (Malcolm, 2011, pp. 178-179). This discretion or restraint in expression does not cancel out the aesthetic beauty that listeners felt, as Yehudi Menuhin's statement proves: "Of all the violinists I met, Enescu obtained the most expressive and varied vibrato and the most wonderful trills" (Malcolm, 2011, 178). Bernard Gavoty (1982) characterizes Enescu's performance as "devoid of artifice", with overflowing sincerity, "an art that does not belong to the spirit, not even to the heart, but to the soul", noting a kind of religiosity with which the score was observed in order to highlight an appropriate tempo, in which "the sense of a proper accent and the inner pulse are more than beautiful, they are true". In the Billboard Magazine of August 26, 1950 it was emphasized that Enescu "can offer most fiddlers a lesson in broad style" (Lascu, 2011, p. 59). Marc Pincherle finds notes of sadness, nostalgia and poetry in the sound obtained in the instrument: "No other intonation resembled his warm, communicative, sometimes a little rough background, something sad and unspeakably moving..." (Cophignon, 2009, p. 366).

Pianist Dinu Lipatti's qualities have similarities to Enescu's, considered to be his spiritual father, and are very detailed in the articles of the time and the testimonies of those who knew him. Lipatti studied with Florica Musicescu at the Conservatory in Bucharest, where she was trying to develop an intellectual approach to the study stages of the instrument, encouraging a mental-auditory representation of the musical works. Thus, he was formed in the spirit of avoiding virtuosity as an attribute that can delight audiences, using it as Walter Legge (EMI music producer) observed over the years, to achieve his "purely musical, interpretative ends", thus taming it with good taste (Lipatti, 2018, p. 114). Pianists such as Béla Síki or Madeleine Lipatti confirm this desire, expressed in the words of the great pianist's wife: "Virtuosity was only a necessary means of expression and not an end in itself." (Lipatti, 2018, p. 20) Jacques Chapuis noticed that Lipatti inserted the elements of virtuosity "into the great architectural lines" (Lipatti, 2018, p. 71). Precisely because he 
managed to overcome that limit of the "champion", as Arthur Honegger (Păsculescu-Florian, 1989, p. 19) called it, he reached a stage of artistic maturity very early, his authenticity being perceived, manifested by the "strict respect for style"; by the sobriety with which he approached the piano works in his repertoire, offering them "such a balanced framework" (Şoarec, 1981, p. 38), he defended his belief: "Music is a serious topic. Do not use music, but serve it!" (Păsculescu-Florian, 1989, back cover). The fidelity to text, however, did not invalidate the qualities that Lipatti strongly believed that he should add to the interpretation: "the heart, the spontaneity, the freedom, the diversity of feelings, etc. ..." (Păsculescu-Florian, 1986, p. 8). His stylistic sense of rare acuity, revealed in a wide-ranging repertoire, from Bach, Mozart, Chopin, to Prokofiev, Bartók or Enescu, made him adapt a different touch and dynamics for each composer, so as to "render the piece as true as possible" through an "effort of meditation and probity", as we are told in a review in Le Ménestrel (Păsculescu-Florian, 1986, pp. 102-103). Béla Síki felt that through this great responsibility felt in front of the score and by "this faith in truth he created a school", an idea supported by Walter Legge, Robert Weisz or Madeleine Lipatti, who stated: "He did not defend his truth, but the Truth." (Lipatti, 2018, pp. 146, 17) Attributes such as truthfulness, purity, simplicity defined him both as a man and as an artist, the proof being the testimonies of musicians such as Nikita Magaloff or Ernest Ansermet (Păsculescu-Florian, 1989, pp. 46, 83). The simplicity perceived by those who listened to him was the equivalent of a sensibility of a matter-of-course, but which was the result of a long search for musical meanings. For the preparation of some pieces, until being presented to the audience, he sometimes allotted much time, ${ }^{3}$ the evidence of a demanding and meticulous analysis that he performed, thus reaching "a rare intensity of feeling, if not unique", as put by Walter Legge (Păsculescu-Florian, 1989, p. 64). Jacques Chapuis even speaks of an "introspection" of the pieces approached, this being the evidence of a deep ripening of the repertoire (Lipatti, 2018, p. 70). Musicians like Alfred Cortot or Herbert von Karajan acknowledged his profound expressiveness, which was approaching the limits of transcendence, as reflected by the words of the great conductor: "That was no longer a piano piece, it was music in its purest form" (Păsculescu-Florian, 1986, p. 9). Qualities such as nobility, refined musicality of a poetic beauty, discretion and clarity, mentioned in publications like La revue musicale or Allehauda, but also by names like Emanoil Ciomac and Madeleine Lipatti, were appreciated in Dinu Lipatti. Last but not least, the variety of sound timbres ${ }^{4}$, which constituted inexhaustible piano resources in his case, was highlighted: "Lipatti possesses the advantage of an exceptional sound that is

\footnotetext{
3 According to Franck Martin or Hédy Salquin

${ }^{4}$ Jacques Chapuis, Hédy Salquin, Nadia Boulanger, Madeleine Lipatti.
} 
never superficial, even in the most subtle hue, without harshness in strength, but of constant plenitude dosed with thoughtful justness" (Șoarec, 1981, p. 38).

Due to these exceptional qualities, Walter Legge's testimony confirms Lipatti as an ideal pianist: "Fashions in interpretation change. [...] I am inwardly convinced that Lipatti's playing, like Schnabel's or Rachmaninov's, is an eternal verity. I cannot believe that the day will come when Lipatti's art will not be acknowledged as the standard by which other future generations will be judged" (Lipatti, 2018, p. 114).

\subsection{Establishing correspondences}

By associating these features of the Romanian ethos with the characteristics of the mentioned artists, we noticed the following correspondences between them:

\begin{tabular}{|l|l|}
\hline $\begin{array}{l}\text { Defining features of Romanian music / } \\
\text { spirituality }\end{array}$ & Features of Romanian performers \\
\hline $\begin{array}{l}\text { "Mioritic space" - solemnity in the face of } \\
\text { transcendence, melancholy, probe into the depths } \\
\text { of the soul }\end{array}$ & sobriety, discretion, "austerity" \\
\hline $\begin{array}{l}\text { 'Dor' (longing) - sadness, overwhelming } \\
\text { nostalgia, pain } \\
\text { - sung for oneself, discretion }\end{array}$ & $\begin{array}{l}\text { the intonation, containing notes of sadness, } \\
\text { poetic musicality }\end{array}$ \\
\hline nobility / distinction & $\begin{array}{l}\text { technique subject to the message / artistic } \\
\text { intention } \\
\text { stylistic sense, balance of dynamics, tempo and } \\
\text { form } \\
\text { aesthetic beauty } \\
\text { maturity, responsibility } \\
\text { refinement }\end{array}$ \\
cantabile character \\
\hline Vocality & $\begin{array}{l}\text { sincerity } \\
\text { deep expressiveness } \\
\text { appropriation, "interiorization" of creations } \\
\text { transcendence }\end{array}$ \\
\hline Transcendence & $\begin{array}{l}\text { purity } \\
\text { simplicity } \\
\text { discretion }\end{array}$ \\
\hline
\end{tabular}

Table 1 Correspondences: characteristics of the Romanian ethos - interpretative features

\section{The case of contemporary artists}

Is this ethnic touch still part of performers' identity? If yes, how perceptible is it? In an attempt to answer these questions, I investigated musical reviews that capture the qualities of contemporary musicians chosen according to a criterion of geographical positioning, and to see if the departure from the Romanian territory would be directly proportional to the diminishing of the interpretative features that could indicate the belonging to the Romanian 
nationality. These are the categories in which we have included these artists and the remarks of the articles that attest the mentioned particularities:

\subsection{Those who were born in Romania and live here}

Pianist Daniel Goiți was appreciated for the warmth and the "out of the ordinary sensibility, chanelled by an irreproachable technique" (genesis.ro site), as well as the artistic sobriety, because "he finds that level of involvement that, through miraculous balance, serves first of all the music, and afterwards personalizes the interpretation" (Frandeș, 2010).

Alexandru Tomescu imposes in his performances or recordings an irreproachable style, regardless of the repertoire addressed.

\subsection{Those who were born in the country, but continued their activity abroad}

Alina Azario wrote down some characteristics of interpretation she has in mind when she is in front of the scores and builds her artistic message: "One approaches music as one approaches religion, probably: with absolute devotion, with purity, [...] with humility" (interview by Aura Marinescu, September 19, 2016, news.ro).

Luiza Borac's personal website features suggestive descriptions of the values that have given her international recognition, a business card that verifies the membership of the Romanian music school, as follows: "Luiza seems to follow Dinu Lipatti's belief of 'do not use music, but serve it' completely" (Diapason); also, the international media considers her "a pianist of unusual poetical expresiveness", as well as having a "subtlety of touch and caressing depth" (4 Stars, The Times). At the same time, she is considered the continuator of a piano tradition, in which a Romanian pattern is noticed: "Listening to Luiza Borac, a performer of a rare balance through the way she transforms her obvious virtuosity into eloquent musicality, you can see reconstructed in an ideal continuity the arcade drawn by the great pianists of her country, who preceded her, Haskil, Lipatti, Lupu" (La Gazzetta di Parma, 2017). Gil Gross (Radio personality NBC, $C B S, K K S F$ ) noted in 2018 the force with which she conveys the artistic message, always finding in it "a sense of communication": "It isn't that she imposes structures on pieces that aren't there, but you are well aware of being in her presence, as if this is not just a performance but as if she needs to tell you something about the music that is personal to her and to you as you hear it. If I could compare that sense to anything it would be what it is like when someone reads a passage from a book or a poem that is especially meaningful to them in the hopes that it affects you as it has them. She has all the virtuoso tools, as is obvious in Enescu's own transcription of his First Romanian Rhapsody, but they are always in the service of imparting something to the listener." Peter Rabinowitz, from the Fanfare magazine, in a review of the recording that included works by 
Schubert, Liszt and Enescu, appreciate her stylistic sense: "You would expect a disc to be uniform in spirit; but while Luiza Borac's remarkable new collection certainly favours a kind of emotional reticence, the recital as a whole is dizzying in its stylistic and expressive richness." He also notes the softness of the sounds and a "rhythmic flexibility" that denotes refinement, possibly related to the Romanian rubato.

In an interview conducted by Dan Burcea, Mara Dobrescu praised the Romanian school, which taught her to be modest, demanding with herself, to offer a cantabile quality "to each note, loving it in a way", and in the spirit of tradition, to continue the Lipattian belief "of technique in the service of music, of expression." Although she considers that each artist has a unique identity, an "energy of his own", she finds herself in a musical sphere together with pianists such as Dinu Lipatti, Clara Haskil or Radu Lupu, through a "window open to the intimate, an unmasked interpretation of great sincerity" (Culture Supplement, no. 660/21-Oct-2019).

\subsection{Those who were born and also live outside Romania, but come from a family of Romanian origin}

The biography on violinist Tartefan Tarara's personal site describes him as having "a brilliant technique coupled with a lean, uncluttered and finely crafted sound that is velvety in the lower registers and exquisitely luminous in the upper. [...] The most remarkable aspect of Mr. Tarara's playing is his artistic maturity, combining an unerring sense of style with deep musicality. Nothing appears forced or rehearsed - it comes from within" (Mannheimer Morgen).

Looking at these biographies, interviews and reviews, I summarized the attributes that indicate the Romanian ethnic specificity in interpretation and I found that they are noticeable regardless of the category in which the artists are placed, even in the case of rarer contacts with their country of origin or family.

\section{Advantages and disadvantages of national identity in interpretation}

In the benefit category I should first of all mention the possibility of understanding a Romanian work, having the advantage of nationality.

Here are some relevant examples present in musicological writings. Valentina Sandu-Dediu (2010) analyzes three versions of Enescu's $3^{\text {rd }}$ Sonata "in a Romanian folk character", considering three duos, according to musicalinterpretative criteria such as character, accomplishment, hierarchy of the culminations and rhythm (parlando-giusto and parlando-rubato): Dinu Lipatti - George Enescu (1943, Electrecord 2001), Valentin Gheorghiu - Ștefan Gheorghiu (1979, Electrecord 2005), Suzanne Stanzeleit - Julian Jacobson (Meridian Records 2002). Her observations point to the fact that the Romanian 
duos have best highlighted the character required by the composer, compared to the third ensemble, which proposes an "objective approach," but which nevertheless respects with admirable fidelity, sobriety and musical intuition all the details (Sandu-Dediu, 2010, pp. 254-255).

In an article dedicated to the Enescian works that were played in the Bucharest festival bearing the name of the Romanian master, Ruxandra Arzoiu (2009) tried to compose a picture of foreign musicians' interpretative perception of our great composer's works. Thus, she synthesized observations similar to Valentina Sandu-Dediu's, supported by fragments from musical articles. Some of the examples mentioned are revealing for this study, as denotes the list below:

- Sonata No. 1, Op. 6 for Violin and Piano, with Saschko Gavriloff and Pierre Laurent Aimard (from 1998): the extensive experience in the artistic field and the repertoire addressed confer a certain "soloistic eloquence" to the German violinist, but this is cataloged by Dumitru Avakian as being "little appropriate for the spirit of the Enescian oeuvres"; he considers that P. L. Aimard understood the character of the work much better, and offers an explanation for this: "He possesses a musical intelligence of a diverse orientation that is materialised in refined piano playing, of an excellent class. He is familiar with the subtleties of the Enescian text both in spirit and letter. Obviously, Aimard reaches the values of the musical text by means of profound knowledge of the important impressionist literature dedicated to this instrument."

- Piano Sonata No. 1, Op. 24, with Gerhard Oppitz (from 2005): although an interesting version, given the convincing message and the attention given to the construction of the piece, the same musical critic reminds the lack of a "timbral transparency", as well as "a Latin type of sensitivity".

- The String Quartet No. 2, Op. 22, with the Vienna Philharmonic Quartet (from 2005): described as "a memorable interpretation" by Paul Codreanu, in the Festival entry of September 15, 2005: "The grandiose compositional process, the variational construction in a kinetic movement that enrobes the subtlety of autobiographic introspection, the oneiric, the unreal spiritualisation, the author's philosophical, all these are comprehended and performed in a exalting way by the Viennese. [...] The rendering of the superb musical phrase was therefore amazing and full of mystery like the author himself."

At the same time, the recordings of the Pavane from the Suite for Piano, Op. 10 by George Enescu - in the interpretation of musicians such as Luiza Borac, Maria Fotino, Daniel Ciobanu or Charles Hamelin, may favour the context conducive to a comparative analysis; without trying to propose a hierarchy of values, however, they show Romanian performers' closer proximity to the composer's character, atmosphere and style. 
Luiza Borac (Avie Records, Germany, March 2003) - described as the "supreme Enescu pianist of our time", with a BBC Music Award received in 2007 for the best instrumental CD of the year (the double compact disc dedicated to the Enescu piano pieces), chosen by the jury out of $1500 \mathrm{CDs}$, and with more than 40,000 public votes, and with the praise of the Gramophone journal: "Borac's only substantial rival is Dinu Lipatti in Enescu's $3^{\text {rd }}$ Sonata" - pays close attention to the melody, which gives the impression that it is sung by voice, thus exceeding the limits of the keyboard instrument, with a warm sound and a luminous virtuosity, which does not place in the centre the technical element, but precisely the continuity of the melodic flow. In a free tempo (but lacking unfit digressions from the composer's indications), in which the agogic is very suggestive, almost narrative in nature, the pianist proposes a refined timbre, with a distinctive care for the accompaniment articulation.

Maria Fotino (recording for Radio Romania, November 1928) colours a different expression, with the most delicate $p p$ or $p p p$, and also a velvety sound. She has a classic, balanced vision of the work, with little agogical boldness, but with a good intuition of the character (for example, the moment noted calme in measure 33 of the score).

Daniel Petrică Ciobanu (Mozarteum Concert, Salzburg, 2013, source: youtube.com) impresses with the qualitative sound and the phrasing that follows the dramatic course of the piece, combined with a controlled rubato and a careful gradation of the tensions. The balance between the melody and the accompaniment favours the emphasis on an atmosphere of mystery, when the dynamics entails it, or a construction of sound that indicates thematic reminiscences.

Charles Hamelin (recording at Studio 12 by Radio-Canada, March 24, 2016, source: youtube.com) has a clarity of piano playing which can be labeled as beautiful, but too concrete at times (even in the introduction, for example, where the composer's indication is quasi flùte), suggesting a baroque approach to the work, quasi-harpsichordist, so that only toward the end the sound approaches the impressionist style, more suited to the writing of this pavane. However, the pianist respects the notations of the score regarding the tempo, dynamic or agogic.

Returning to the enumeration of the advantages found in the context of asserting the national identity in the act of the musical performance, we can also mention:

- the diversity of interpretations in the artistic environment;

- the analytical depth, the construction and transmission of the message;

- the balance and stylistic adequacy - Romanian performers can reach coherent representations due to a positioning that we could call "median", far from extreme qualities, but endowed with nobility, discretion, expression; 
- the richness of the aesthetic and rhetorical plane - the image is realized from the perspective of some defining cultural elements, specifically Romanian.

The subjection of any repertoire to one's own set of interpretative qualities could be considered a disadvantage for the manifestation of the particularities on which this research was focused.

\section{Conclusions}

The research of the materials containing information on musicians of Romanian origin was materialized in a synthesis study, which confers undoubtful evidence on the existence of features that bear the imprint of nationality in interpretation, which bring to light the identity of the musician. Violinist Șerban Lupu (2011) states in a conversation with Irina Boga the need for the presence of national landmarks in the perception of identity: "Being away from home in those college years, America proved to be a fascinating and extraordinary country, but one can easily lose one's identity in that amalgam of characters, of nations... And so, I needed something very powerful to cling myself to. As a consequence, I focused on the Romanian culture." Enescu's music was a valve of restoring personal and artistic feeling: "he (Enescu) came into my heart and soul to heal my homesickness and to enlarge my trust and strenghten my identity. And I, in turn, I honored the memory of our great composer, spreading his music to every corner where I happened to be playing during my artistic existence."

At the same time, the positive assessments by specialized foreign journals of Romanian artists' recordings, some of them awarded in international competitions, or the favourable remarks from critics all over the world reveal the recognition of the value of a tradition which the musicians assert and carry on, being aware of its role as a trainer and of the advantages attributed to identity features.

To conclude, this present study may open new horizons for research on this topic, being useful to theorists, but also to performers alike, as a plea for preserving the defining qualities of the Romanian ethos.

\section{References}

Arzoiu, R. (2009). New Interpretative Versions of Enescu's Opuses in Recent Editions of the International "George Enescu" Festival. "George Enescu" International Musicology Symposium. George Enescu from a contemporary perspective. Aesthetic and stylistic considerations. Bucharest, September 5-8, 2007, 272-287. București: Editura Muzicală.

Blaga, L. (2011). Spaţiul mioritic [The Mioritic Space]. In Trilogia culturii [The Trilogy of Culture] (pp. 157-173). București: Humanitas. 
Cophignon, A. (2009). George Enescu. București: Editura Institutului Cultural Român.

Doron, R. \& Parot, F. (coord.) (1999). Dicționar de psihologie [Dictionary of Psychology]. București: Humanitas.

Enescu, G. (1956). Suita pentru pian op. 10 [Suite for Piano, Op. 10]. București: Editura de Stat pentru Literatură și Artă.

Gavoty, B. (1982). Amintirile lui George Enescu [George Enescu's Memories]. București: Editura Muzicală.

Lascu, C. (2011). Recordings with George Enescu as a Performer. Proceedings of the "George Enescu" International Musicology Symposium. George Enescu from knowledge to recognition (part II), 57-62. București: Editura Muzicală.

Lipatti, M. (2018). In memoriam Dinu Lipatti: Hommages [In memoriam: Dinu Lipatti: homages]. București: Grafoart.

Lupu, Ș. (2011). Enescu necunoscut - pagini componistice redescoperite [The Unknown Enescu - Rediscovered Compositional Pages]. București: Editura Casa Radio.

Malcolm, N. (2011). George Enescu. Viața și muzica [George Enescu. His Life and Music]. București: Humanitas.

Păsculescu-Florian, C. (1989). Dinu Lipatti. Pagini din jurnalul unei regăsiri [Dinu Lipatti. Pages from a Diary of Recovery]. București: Editura Muzicală.

Păsculescu-Florian, C. (1986). Vocație şi destin. Dinu Lipatti [Vocation and Destiny. Dinu Lipatti]. București: Editura Muzicală.

Petra-Basacopol, C. (1979). L' originalité de la musique roumaine à travers les oeuvres de chambre et de scène d Enesco, Jora et Constantinesco [The Originality of Romanian Music through Enesco, Jora and Constantinesco's Chamber and Stage Works]. București: Editura Muzicală.

Sandu-Dediu, V. (2017). George Enescu: imagini postume [George Enescu. Posthumous images]. In In căutarea consonanțelor [Searching for Consonances] (pp. 85-98). București: Humanitas.

Sandu-Dediu, V. (2010). Unele considerații asupra stilisticii interpretative [Some considerations on interpretative aspects]. In Alegeri, atitudini, afecte. Despre stil și retorică în muzică [Choice, Attitude, Affect. Style and Rhetoric in Music] (pp. 224258). București: Editura Didactică și Pedagogică.

Șchiopu, U. (coord.) (1997). Dicționar Enciclopedic de Psihologie [Encyclopaedic Dictionary of Psychology]. București: Babel.

Şoarec, M. (1981). Prietenul meu Dinu Lipatti [My Friend Dinu Lipatti]. București: Editura Muzicală.

Online sources (accessed between October - December 2019) 
https://www.genesis.ro/ro/component/content/article?id=152:recital-daniel-goiti-laateneul-roman\&Itemid $=685$

https://agenda.liternet.ro/articol/11171/Marcel-Frandes/Sunete-etajate-armoniospianistul-Daniel-Goiti.html

https://www.news.ro/cultura-media/interviu-pianista-alina-azario-fondatoareafestivalului-clara-haskil-de-30-de-ani-nivelul-general-al-muzicienilor-este-inascensiune-1922401019002016091415570980

https://www.luizaborac.com/

http://suplimentuldecultura.ro/28943/interviu-cu-pianista-mara-dobrescu-un-artist-deorice-nationalitate-ar-fi-el-poarta-in-el-o-energie-un-suflu-propriu-un-ceva-care-nu-seinvata-care-se-simte-se-traieste/

https://www.stefan-tarara.com/en/biography/ 